\title{
Synthesis and First Molecular Structure of a Bis- 2-Spiro-1-Boraadamantane Derivative
}

\author{
Carl E. Wagner and Kenneth J. \\ Shea* \\ Department of Chemistry, University of \\ California Irvine, Irvine, CA 92697
}

\section{Experimentals}

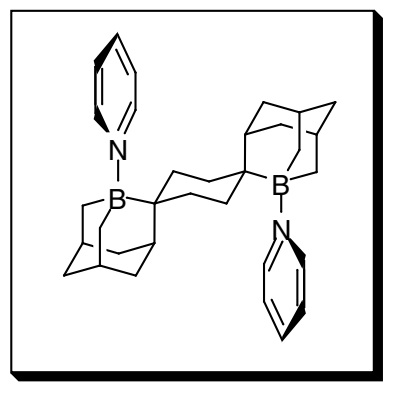

1,4-Bis(2-spiro-1-boraadamanyl)cyclohexane-dipyridine (1). In a 2-neck, 50-mL round bottom flask equipped with a condenser, a stir bar and a Merlic solid addition tube charged with 1,4-diethynyl-1,4dimethoxyether (7) $(1.1 \mathrm{~g}, 5.7 \mathrm{mmol})$ was added triallylborane $(2.0$ $\mathrm{mL}, 11.5 \mathrm{mmol})$. The triallylborane was heated to $140{ }^{\circ} \mathrm{C}$ in an oil bath with stirring ( $5 \mathrm{~min}$ ) and 7 was slowly added and dissolved into the stirring triallylborane. The resulting reaction solution briefly refluxed and turned from a colorless liquid to a deep canary yellow. After stirring the reaction at $140{ }^{\circ} \mathrm{C}(1 \mathrm{~h})$, the reaction was cooled to room temperature, and THF $(0.5 \mathrm{~mL})$ and methanol $(0.52 \mathrm{~mL}, 12.8 \mathrm{mmol})$ were added slowly. The residual THF and methanol was removed under high vacuum $(0.10 \mathrm{~mm} \mathrm{Hg})$, and the solid yellow residue was dissolved in THF $(6.0 \mathrm{~mL})$. To this solution stirring at room temperature, a solution of borane THF $(15.0 \mathrm{~mL}, 1.0 \mathrm{M}, 15 \mathrm{mmol})$ was added. The reaction was refluxed for 1h, and excess THF was removed by distillation under atmospheric pressure of nitrogen. The white foamy residue was dissolved in benzene $(10.0 \mathrm{~mL})$ to form a clear, colorless solution. Upon the addition of pyridine $(0.94 \mathrm{~mL}, 11.6 \mathrm{mmol})$, the colorless solution turned orange. The 
crude solution was chromatographed $\left(\mathrm{SiO}_{2}, \mathrm{Hex}\right.$ :Benzene 1:1) to give $\mathbf{1}$ as an off-white crystalline solid (0.100 g, 4\%) m.p. $267-270{ }^{\circ} \mathrm{C}:{ }^{1} \mathrm{H}$ NMR $\left(500 \mathrm{MHz}, \mathrm{C}_{6} \mathrm{D}_{6}\right) \delta 8.18(\mathrm{~d}, J=6.5$, $4 \mathrm{H}), 6.57(\mathrm{t}, J=7.6,2 \mathrm{H}), 6.29(\mathrm{t}, J=6.6,4 \mathrm{H}), 2.75(\mathrm{~s}, 4 \mathrm{H}), 2.42(\mathrm{~d}, J=12.0,4 \mathrm{H}), 2.06(\mathrm{~d}, J=$ $5.2,8 \mathrm{H}), 1.97(\mathrm{~s}, 2 \mathrm{H}), 1.77(\mathrm{~d}, J=12.3,4 \mathrm{H}), 1.68(\mathrm{~d}, J=11.6,4 \mathrm{H}), 1.06(\mathrm{~d}, J=9.6,4 \mathrm{H}), 0.79$ $(\mathrm{d}, J=11.1,4 \mathrm{H}) ;{ }^{13} \mathrm{C}$ NMR $\left(125.8 \mathrm{MHz}, \mathrm{C}_{6} \mathrm{D}_{6}\right) \delta 145.5,138.3,123.9,42.6,35.9,34.0,33.1$, 24.3; IR (neat) 2856, 1616, 1453, 1079, 983, 761, $691 \mathrm{~cm}^{-}$; Anal. Calcd for $\mathrm{C}_{32} \mathrm{H}_{44} \mathrm{~B}_{2} \mathrm{~N}_{2}$ : C 80.35; H 9.27; N 5.86. Found: C 80.43; H 9.39, N 5.85.

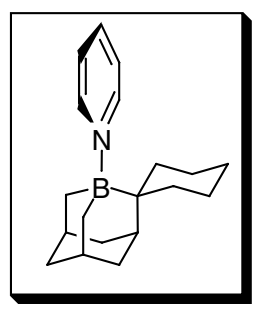

2-Spiro-1-boraadamantane·pyridine (2). To the borabicycle 6 (1.98 g, 7.6 mmol) was added a solution of borane-THF in THF (10.0 mL, 1M, $10 \mathrm{mmol})$, and the reaction was refluxed for $1 \mathrm{~h}$. The excess THF was removed by distillation to give a crude, white solid. The crude product was dissolved in benzene $(4.0 \mathrm{~mL})$. Upon addition of pyridine $(0.7 \mathrm{~mL}, 8.7 \mathrm{mmol})$, a crude ppt. was observed. The ppt. was filtered and washed with cold benzene $(10.0 \mathrm{~mL})$. The ppt was found to be pure 2 by NMR (1.19 g, 56\% yield). A small portion of $2(50.0 \mathrm{mg})$ was recrystallized in 1:1 acetone:isopropanol to give 2 as a clear, colorless crystalline compound, m.p. $197-198{ }^{\circ} \mathrm{C}:{ }^{1} \mathrm{H}$ NMR (500 MHz, $\left.\mathrm{CDCl}_{3}\right) \delta 8.47(\mathrm{dd}, J=5.2,1.4,2 \mathrm{H}), 7.92(\mathrm{t}, J=7.6,1 \mathrm{H}), 7.53(\mathrm{t}, J=7.4,2 \mathrm{H})$, $2.22(\mathrm{~s}, 3 \mathrm{H}), 2.07(\mathrm{~d}, J=12.8,2 \mathrm{H}), 1.94(\mathrm{~d}, J=12.9,2 \mathrm{H}), 1.65(\mathrm{~d}, J=11.8,1 \mathrm{H}), 1.46(\mathrm{~m}, 6 \mathrm{H})$, $1.33(\mathrm{~d}, J=10.9,2 \mathrm{H}), 1.13(\mathrm{~d}, J=13.6,2 \mathrm{H}), 0.78(\mathrm{~m}, 1 \mathrm{H}), 0.37(\mathrm{~d}, J=10.7,2 \mathrm{H}), 0.30(\mathrm{t}, J=$ $12.9,2 \mathrm{H}) ;{ }^{13} \mathrm{C} \mathrm{NMR}\left(125.8 \mathrm{MHz} \mathrm{CDCl}_{3}\right) \delta 145.4,138.5,124.0,41.3,34.5,32.9,32.6,30.9$, 27.7, 27.1 (br), 20.4; ${ }^{11} \mathrm{~B}$ NMR (237 MHz, $\mathrm{CDCl}_{3}$ ) $\delta$-1.4; IR (KBr) 2998, 1453, 1253, 1077, 690 cm; Anal. Calcd for $\mathrm{C}_{19} \mathrm{H}_{28} \mathrm{BN}$ : C 81.14; H 10.03; N 4.98. Found: C 81.29; H 10.14; N 4.99.

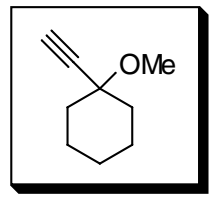

1-Ethynylcyclohexylmethyl ether (5). To a solution of 1-ethynylcyclohexanol $(8.0 \mathrm{~g}, 64 \mathrm{mmol})$ in $100 \mathrm{~mL}$ of DMF cooled to $0{ }^{\circ} \mathrm{C}$ was slowly added sodium hydride $(2.0 \mathrm{~g}, 81 \mathrm{mmol})$. After stirring at $0{ }^{\circ} \mathrm{C}$ for $20 \mathrm{~min}$, methyl iodide (4.9 $\mathrm{mL}, 79 \mathrm{mmol}$ ) was added. The solution was warmed to r.t. and the DMF was extracted with 
ether $(400 \mathrm{~mL})$ and water $(200 \mathrm{~mL})$. The ether was washed with water $(200 \mathrm{~mL})$ and the combined aqueous washes were extracted with ether $(4 \times 100 \mathrm{~mL})$. The combined ether extracts were concentrated in vacuo and the crude oil was chromatographed $\left(\mathrm{SiO}_{2}\right.$, hexanes) to give $\mathbf{5}$ as a light yellow, viscous oil (6.6 g, $75 \%):{ }^{1} \mathrm{H}$ NMR (500 MHz, $\left.\mathrm{CDCl}_{3}\right) \delta 3.36(\mathrm{~s}, 3 \mathrm{H}), 2.46(\mathrm{~s}, 1 \mathrm{H})$, $1.89(\mathrm{~m}, 2 \mathrm{H}), 1.65(\mathrm{~m}, 2 \mathrm{H}), 1.51(\mathrm{~m}, 5 \mathrm{H}), 1.29(\mathrm{~m}, 1 \mathrm{H}) ;{ }^{13} \mathrm{C} \mathrm{NMR}\left(125.8 \mathrm{MHz}, \mathrm{CDCl}_{3}\right) \delta 84.9$, 73.7, 50.6, 36.6, 25.4, 22.6; IR (neat) 3307, 2937, 1448, 1343, 1287, $1258 \mathrm{~cm}^{\circ}$; HRMS (EI) $\mathrm{m} / \mathrm{z}$ calcd for $\mathrm{C}_{9} \mathrm{H}_{14} \mathrm{O}(\mathrm{M})^{+}$138.1045, found 138.1040.

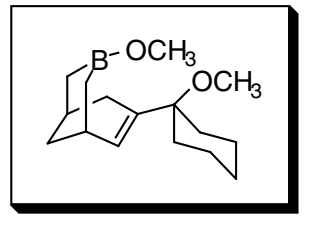

Borabicycle (6). To triallylborane $(5.2 \mathrm{~mL}, 30 \mathrm{mmol})$ at $135^{\circ} \mathrm{C}$ was slowly added with stirring 1-ethynylcyclohexylmethyl ether $(4.5 \mathrm{~mL}, 30 \mathrm{mmol})$. The reaction was stirred at $135-145^{\circ} \mathrm{C}(1 \mathrm{~h})$, and then cooled to r.t. Methanol (1.4 mL, $35 \mathrm{mmol}$ ) was added dropwise with stirring, and propene slowly evolved. The crude viscous reaction product was vacuum distilled $\left(110^{\circ} \mathrm{C}, 0.05 \mathrm{~mm} \mathrm{Hg}\right)$ to give the borabicycle 6 as a slightly yellow, viscous oil (5.64 g, 72\%): ${ }^{1} \mathrm{H}$ NMR (500 MHz, $\left.\mathrm{CDCl}_{3}\right) \delta 5.61(\mathrm{~s}, 1 \mathrm{H}), 3.57$ (s, 3H), $2.92(\mathrm{~s}, 3 \mathrm{H}), 2.52(\mathrm{~s}, 1 \mathrm{H}), 2.45(\mathrm{~s}, 1 \mathrm{H}), 2.14(\mathrm{~d}, J=17.3,1 \mathrm{H}), 1.83-1.35(\mathrm{~m}, 11 \mathrm{H}), 1.19(\mathrm{~m}$, $1 \mathrm{H}), 1.05(\mathrm{~m}, 1 \mathrm{H}), 0.92-0.83(\mathrm{~m}, 4 \mathrm{H}) ;{ }^{13} \mathrm{C} \mathrm{NMR}\left(125.8 \mathrm{MHz}, \mathrm{CDCl}_{3}\right) \delta 135.5,130.6,53.0,48.5$, $33.8,32.5,32.4,31.6,29.5,27.3,26.0,25.9,25.0$ (br), 21.9, 21.9; ${ }^{11} \mathrm{~B} \mathrm{NMR}\left(237 \mathrm{MHz}, \mathrm{CDCl}_{3}\right) \delta$ 55.0; IR (neat) 3386, 2933, 1464, 1373, 1348, 1299, 1254, 1216, 1164, 1074 cm; HRMS (EI) $m$ / $z$ calcd for $\mathrm{C}_{16} \mathrm{H}_{27} \mathrm{BO}_{2}(\mathrm{M})^{+}$262.2107, found 262.2103.

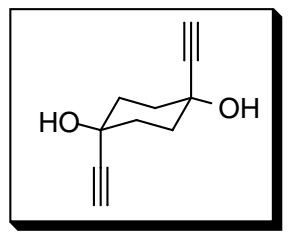

Trans-1,4-diethynyl-1,4-diol (7). To a solution of 1,4-cyclohexanedione (1.0 $\mathrm{g}, 8.9 \mathrm{mmol})$ in THF $(10 \mathrm{~mL})$ was added a solution of lithium trimethylsilylacetylide $(41.0 \mathrm{~mL}, 0.48 \mathrm{M}, 20.0 \mathrm{mmol})$ in THF with stirring at

$0{ }^{\circ} \mathrm{C}$. The reaction was allowed to warm to room temperature and quenched with an aqueous solution of saturated ammonium chloride $(6.0 \mathrm{~mL})$. The diol was extracted with diethyl ether $(30.0 \mathrm{~mL})$. The ether layer was washed with water $(10.0 \mathrm{~mL})$, saturated sodium bicarbonate $(10.0 \mathrm{~mL})$ and saturated sodium chloride $(10.0 \mathrm{~mL})$. The ether layer was dried over sodium 
sulfate, concentrated in vacuo, chromatographed $\left(\mathrm{SiO}_{2}, \mathrm{CHCl}_{3}\right)$, and recrystallized in $\mathrm{THF}$ to give trans-1,4-bis(trimethylsilylethynyl)cyclohexane-1,4-diol as a transparent, colorless crystalline solid $(0.93 \mathrm{~g}, 34 \%)$. To a solution of trans-1,4-bis(trimethylsilylethynyl)cyclohexane1,4-diol (2.0 g, $6.5 \mathrm{mmol})$ was added a solution of tetrabutylammonium fluoride trihydrate (3.8 $\mathrm{g}, 14.5 \mathrm{mmol})$ in THF $(32.0 \mathrm{~mL})$ with stirring at $0{ }^{\circ} \mathrm{C}$. The reaction was allowed to warm to room temperature and was stirred (1h). After the reaction was judged complete by TLC, excess THF was removed in vacuo, and the crude residue was dissolved in warm EtOAc $(20.0 \mathrm{~mL})$ with methanol $(1.0 \mathrm{~mL})$ and chromatographed $\left(\mathrm{SiO}_{2}\right.$, EtOAc) to give trans-1,4-diethynyl-1,4-diol (7) as a white solid (1.06 g, 99\%) m.p. $198-199{ }^{\circ} \mathrm{C}:{ }^{1} \mathrm{H}$ NMR $\left(500 \mathrm{MHz}, \mathrm{S}(\mathrm{O})\left(\mathrm{CD}_{3}\right)_{2}\right) \delta 5.40(\mathrm{~s}, 2 \mathrm{H})$, $3.30(\mathrm{~s}, 2 \mathrm{H}), 1.77(\mathrm{~d}, J=8.5,4 \mathrm{H}), 1.64(\mathrm{~d}, J=8.9,4 \mathrm{H}) ;{ }^{13} \mathrm{C} \mathrm{NMR}\left(125.8 \mathrm{MHz}, \mathrm{S}(\mathrm{O})\left(\mathrm{CD}_{3}\right)_{2}\right) \delta$ 88.6, 73.4, 65.5, 35.8; IR (neat) 3297, 2970, 1437, 1356, 1259, 1084, 993, 680, 625 cm; Anal. Calcd for $\mathrm{C}_{10} \mathrm{H}_{12} \mathrm{O}_{2}$ : C 73.15; H 7.37. Found: C 73.12; H 7.42; HRMS (CI) $m$ / $z$ calcd for $\mathrm{C}_{10} \mathrm{H}_{11} \mathrm{O}_{2}(\mathrm{M}-\mathrm{H})^{+}$163.0759, found 163.0755.

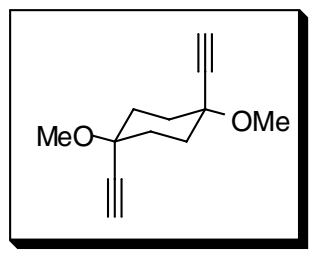

Trans-1,4-diethynyl-1,4-dimethoxyether (8). To a solution of trans-1,4diethynyl-1,4-diol (7) (1.1 g, $6.7 \mathrm{mmol})$ in DMF (23 mL) was added sodium hydride $(0.6 \mathrm{~g}, 24.8 \mathrm{mmol})$ with stirring at $0{ }^{\circ} \mathrm{C}$. The reaction was allowed to warm to room temperature with stirring $(20 \mathrm{~min})$. The reaction was cooled to $0{ }^{\circ} \mathrm{C}$ and iodomethane $(1.6 \mathrm{~mL}, 25.7 \mathrm{mmol})$ was slowly added with stirring. The reaction was warmed to room temperature and stirred (2h). After the reaction was complete, water $(40.0 \mathrm{~mL})$ was added, and the solution was extracted with diethyl ether. The ether layer was washed with water, dried over sodium sulfate and concentrated in vacuo. The crude residue was dissolved in EtOAc and chormatographed $\left(\mathrm{SiO}_{2}\right.$, Hex:EtOAc 23:2) to give $\mathbf{8}$ as transparent, colorless crystals $(1.18 \mathrm{~g}, 92 \%)$ m.p. $102-103{ }^{\circ} \mathrm{C}:{ }^{1} \mathrm{H}$ NMR $\left(500 \mathrm{MHz}, \mathrm{CDCl}_{3}\right) \delta 3.38(\mathrm{~s}, 6 \mathrm{H})$, $2.48(\mathrm{~s}, 2 \mathrm{H}), 1.99(\mathrm{~d}, J=8.8,4 \mathrm{H}), 1.86(\mathrm{~d}, J=8.8,4 \mathrm{H}) ;{ }^{13} \mathrm{C} \mathrm{NMR}\left(125.8 \mathrm{MHz}, \mathrm{CDCl}_{3}\right) \delta 84.1$, 73.9, 72.4, 51.1, 32.2; IR (neat) 3219, 2959, 2096, 1463, 1285, 1092, 986, 919, 708, 509 cm; 
Anal. Calcd for $\mathrm{C}_{12} \mathrm{H}_{16} \mathrm{O}_{2}$ : C 74.97; $\mathrm{H}$ 8.39. Found: C 75.04; $\mathrm{H}$ 8.36; HRMS (CI) $m$ / $z$ calcd for $\mathrm{C}_{12} \mathrm{H}_{15} \mathrm{O}_{2}(\mathrm{M}-\mathrm{H})^{+}$191.1072, found 191.1067.

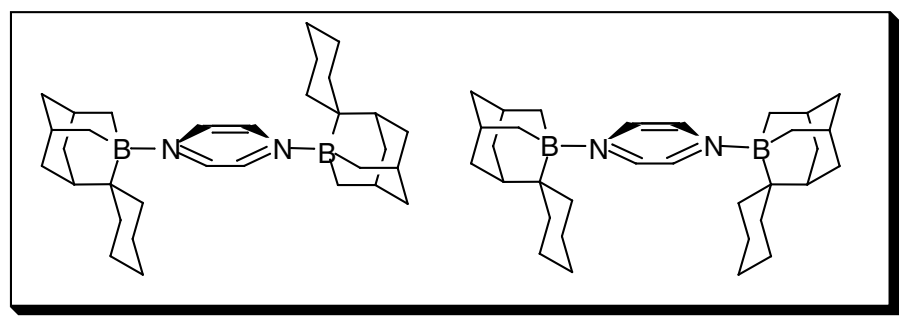

\section{Bis(2-spiro-1-} boraadamantane)·pyrazine (9) and (10). To borabicycle (6), neat $(3.45 \mathrm{~g}$, $13.1 \mathrm{mmol}$ ) in a $50 \mathrm{~mL}, 2$-neck round bottom flask equiped with a condenser under nitrogen was added a solution of borane-THF (15.0 $\mathrm{mL}, 1 \mathrm{M})$ and the reaction was refluxed (1h). Excess THF was removed by distillation under nitrogen. The crude white residue was dissolved in benzene $(10.0 \mathrm{~mL})$ to give a colorless solution, and to this solution was added a solution of pyrazine $(0.57 \mathrm{~g}, 7.1 \mathrm{mmol})$ in benzene (3.0 mL). The resulting crimson red solution was cooled to $0{ }^{\circ} \mathrm{C}$, and a bright red precipitate was subsequently isolated by filtration. The precipitate was washed with cold benzene and dried under high vacuum to give a 1:1 mixture of the bis-(2-spiro-1-boraadamantane)-pyrazine adducts (9) and (10) as an air stable brilliant red powder (1.14 g, 36\%): ${ }^{1} \mathrm{H}$ NMR (500 MHz, $\left.\mathrm{CDCl}_{3}\right) \delta$ $8.92(\mathrm{~s}, 2 \mathrm{H}), 8.38(\mathrm{~s}, 2 \mathrm{H}), 2.23(\mathrm{~s}, 6 \mathrm{H}), 2.05(\mathrm{~d}, J=12.6,4 \mathrm{H}), 1.94(\mathrm{~d}, J=12.9,4 \mathrm{H}), 1.50(\mathrm{~m}$, 14H), $1.20(\mathrm{~m}, 6 \mathrm{H}), 0.80(\mathrm{~m}, 4 \mathrm{H}), 0.39(\mathrm{~m}, 4 \mathrm{H}), 0.20(\mathrm{~m}, 4 \mathrm{H}) ;{ }^{13} \mathrm{C} \mathrm{NMR}\left(125.8 \mathrm{MHz}, \mathrm{CDCl}_{3}\right) \delta$ 128.3, 34.2, 32.3, 32.1, 30.6, 29.7, 27.5, 26.7 (br), 20.4 (br); IR (KBr) 2990 cm; Anal. Calcd for $\mathrm{C}_{32} \mathrm{H}_{50} \mathrm{~B}_{2} \mathrm{~N}_{2}$ : C 79.35; H 10.40; N 5.78. Found: C 79.45; H 10.35; N 5.85. 